\title{
Interactions of antitumor triazoloacridinones with DNA
}

\author{
Marcin Koba ${ }^{\star}$ and Jerzy Konopa ${ }^{\bowtie}$ \\ Department of Pharmaceutical Technology and Biochemistry, Gdańsk University of Technology, Gdańsk, Poland
}

Received: 12 February, 2007; revised: 20 March, 2007; accepted: 21 March, 2007

available on-line: 19 April, 2007

\begin{abstract}
Triazoloacridinones (TA) are a new group of potent antitumor compounds, from which the most active derivative, C-1305, has been selected for extended preclinical trials. This study investigated the mechanism of TA binding to DNA. Initially, for selected six TA derivatives differing in chemical structures as well as cytotoxicity and antitumor activity, the capability of noncovalent DNA binding was analyzed. We showed that all triazoloacridinones studied stabilized the DNA duplex at a low-concentration buffer but not at a salt concentration corresponding to that in cells. DNA viscometric studies suggested that intercalation to DNA did not play a major role in the mechanism of the cytotoxic action of TA. Studies involving cultured cells revealed that triazoloacridinone C-1305 after previous metabolic activation induced the formation of interstrand crosslinks in DNA of some tumor and fibroblast cells in a dose dependent manner. However, the detection of crosslink formation was possible only when the activity of topoisomerase II in cells was lowered. Furthermore, it was impossible to validate the relevance of the ability to crosslink DNA to biological activity of TA derivatives.
\end{abstract}

Keywords: triazoloacridinones, DNA intercalation, DNA interstrand crosslinks, structure-activity relationship, biological activity, metabolic activation

\section{INTRODUCTION}

Triazoloacridinones (TA) (see Table 1, for structures) are a class of antitumor agents synthesized in our laboratory (Cholody et al., 1990). TA exhibited high cytotoxic activity against a broad spectrum of tumor cell lines in vitro and high antitumor activity against transplantable tumors such as leukemia P388, melanoma B16, ascites colon 26 adenocarcinoma and colon 38 adenocarcinoma in mice (Cholody et al., 1990; Kusnierczyk et al., 1994). The most active and promising derivate from the TA group, C-1305, was selected for extended preclinical trials.
Previous investigations demonstrated that triazoloacridinones inhibited cleavable complexes of topoisomerase II-DNA and also the catalytic activity of this enzyme (Skladanowski et al., 1999; Lemke et al., 2004), as well as induced $G_{2}$ block of the cell cycle followed by apoptosis (Augustin \& Konopa, 1999; Augustin et al., 2000; 2006). These effects suggested that cellular DNA might be an important target for the TA drugs. Triazoloacridinone C-1305 strongly inhibited proliferation of cells lacking poly(ADP-ribose) polymerase 1 (PARP-1), which was a surprising observation because such cells are generally resistant to other topoisomerase II poisons (WęsierskaGądek et al., 2004). Moreover, recent data obtained

\footnotetext{
$\triangle$ Corresponding author: J. Konopa, Department of Pharmaceutical Technology and Biochemistry, Gdańsk University of Technology, G. Narutowicza 11/12, 80-952 Gdańsk, Poland; phone/fax: (+48 58) 347 1516; e-mail: konopa@chem.pg.gda.pl $\star$ Present address: Department of Drug Chemistry, Faculty of Pharmacy, Collegium Medicum of Nicolaus Copernicus University, Bydgoszcz, Poland.

Abbreviations: ATA, aurintricarboxylic acid; bp, base pairs; ctDNA, calf thymus DNA; DMEM, Dulbecco's modified Eagle's medium; FCR, fraction of crosslinked DNA; FCS, fetal calf serum; MEM, minimal essential medium; PBS, phosphate-buffered saline; POPOP, 1,4-bis-(5-phenyl-2-oxazolyl)-benzene; PPO, 2,5-diphenyl-oxazole; SDS, sodium dodecylsulfate; SRB, sulforhodamine; topo II, topoisomerase II; TA, triazoloacridinones.
} 
Table 1. Chemical structures and biological activities of triazoloacridinones studied. Values are means \pm S.D. from at least three independent experiments.

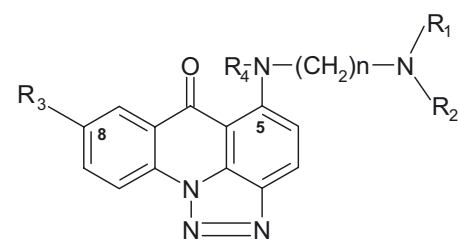

\begin{tabular}{|c|c|c|c|c|c|c|c|c|}
\hline \multirow{4}{*}{ Compound } & \multicolumn{5}{|c|}{ Chemical structure } & \multicolumn{3}{|c|}{ Biological activity } \\
\hline & \multirow{3}{*}{$n$} & \multirow{3}{*}{$R_{1}$} & \multirow{3}{*}{$R_{2}$} & \multirow{3}{*}{$R_{3}$} & \multirow{3}{*}{$R_{4}$} & \multirow{3}{*}{$\frac{{ }^{\mathrm{a} C e l l s} \text { in vitro }}{\mathrm{HeLa}_{3}}$} & \multicolumn{2}{|c|}{${ }^{\text {bP388 leukemia in mice }}$} \\
\hline & & & & & & & OD & ILS \\
\hline & & & & & & & $\left(\mathrm{mg} \mathrm{kg}^{-1}\right)$ & $(\%)$ \\
\hline C-1233 & 2 & $\mathrm{CH}_{3}$ & $\mathrm{CH}_{3}$ & $\mathrm{H}$ & $\mathrm{H}$ & $37.6 \pm 0.55$ & 100 & 77.0 \\
\hline C-1296 & 3 & $\mathrm{CH}_{3}$ & $\mathrm{CH}_{3}$ & $\mathrm{CH}_{3}$ & $\mathrm{H}$ & $7.6 \pm 0.32$ & 100 & 18.0 \\
\hline C-1303 & 2 & $\mathrm{CH}_{3}$ & $\mathrm{CH}_{3}$ & $\mathrm{OH}$ & $\mathrm{H}$ & $2.8 \pm 0.78$ & 25 & 102.0 \\
\hline C-1305 & 3 & $\mathrm{CH}_{3}$ & $\mathrm{CH}_{3}$ & $\mathrm{OH}$ & $\mathrm{H}$ & $8.6 \pm 0.32$ & 25 & 165.0 \\
\hline C-1533 & 2 & $\mathrm{CH}_{3}$ & $\mathrm{CH}_{3}$ & $\mathrm{OH}$ & $\mathrm{CH}_{3}$ & $37.4 \pm 0.23$ & 25 & 9.5 \\
\hline C-1567 & 2 & $\mathrm{CH}_{3}$ & $\mathrm{CH}_{3}$ & $\mathrm{C}\left(\mathrm{CH}_{3}\right)_{3}$ & $\mathrm{H}$ & $27.2 \pm 0.93$ & ${ }^{\mathrm{c}} \mathrm{N}$ & 0.0 \\
\hline
\end{tabular}

${ }^{\mathrm{a}} \mathrm{EC}_{50}$, the concentration of the compound inhibiting growth of cells by $50 \%$ after $72 \mathrm{~h}$ incubation. ${ }^{\mathrm{b}}$ Data taken from (Cholody et al., 1990). $\mathrm{OD}$, the optimal dose and ILS is the increase in survival time of treated to control animals at optimal dose. ${ }^{\mathrm{C}} \mathrm{N}$, means that the compound was not active.

in our department indicated that triazoloacridinone C-1305 preferentially intercalated to DNA in guanine triplet regions and induced specific changes in DNA structures (Lemke et al., 2005). The structural resemblance of triazoloacridinones to other anticancer drugs, such as imidazoacridinones (Cholody et al., 1992; Kusnierczyk et al., 1994; Dziegielewski et al., 2002) and anthracenediones (Kapuscinski \& Darzynkiewicz, 1985; Skladanowski et al., 2000) (flat structure of aromatic acridine ring (Arjunan et al., 1993) and diamino alkylamino group in the side chain) indicated that DNA binding, including interstrand crosslinking of DNA, may play a role in the TA mechanism of action.

In this study, we examined the TA capability of intercalation to DNA and formation of interstrand crosslinks in cellular DNA, and tried to evaluate the importance of these phenomena for the biological activity of these compounds by correlation analysis.

\section{MATERIALS AND METHODS}

Chemicals. Triazoloacridinones were resynthesized and purified as described earlier (Cholody et al., 1990) by Dr. Barbara Horowska from this department and were dissolved in water. Aurintricarboxylic acid (ATA) and sodium dodecylsulfate (SDS) were from Serva (Heidelberg, Germany); $\mathrm{NaClO}_{4}$ was from Fluka (Sigma-Aldrich, Poland); 2,5-diphenyl-oxazole (PPO) and 1,4-bis-(5-phenyl-2-oxazolyl)benzene (POPOP) were from Merck (Darmstadt, Germany); methyl- $\left[{ }^{14} \mathrm{C}\right]$ thymidine was from Amersham International (Amersham, UK) and other rea- gents were from Sigma-Aldrich (Poznań, Poland). All reagents used were at least of the analytical grade. Ultra pure water $(18 \mathrm{M} \Omega)$ was used in all experiments.

Cell culture and media. HL60 (human myeloblastic leukemia), $\mathrm{HeLa}_{3}$ (human cervix carcinoma) and NIH 3T3 (mouse fibroblasts) cell lines were cultivated at $37^{\circ} \mathrm{C}$ in $5 \% \mathrm{CO}_{2} /$ air atmosphere in appropriate culture medium (HL60: RPMI-1640, $5 \%$ FCS; HeLa S 3 : MEM, 5\% FCS; NIH 3T3: DMEM, $10 \%$ FCS, respectively) supplemented with $100 \mu \mathrm{g} /$ $\mathrm{ml}$ streptomycin, $100 \mathrm{U} / \mathrm{ml}$ penicillin. The RPMI1640 medium, minimal essential medium (MEM) and Dulbecco's modified Eagle's medium (DMEM) supplemented with $1000 \mathrm{mg} / \mathrm{l}$ glucose and fetal calf serum (FCS) were from Gibco Europe Ltd (Paisley, UK); antibiotics were from Sigma-Aldrich (Poznań, Poland); proteinase $\mathrm{K}$ was from Merck (Darmstadt, Germany); nuclease S1 was from Fermentas (Vilnius, Lithuania); sulforhodamine (SRB) and calf thymus DNA (ctDNA, type II) were from Sigma-Aldrich (Poznań, Poland).

Growth inhibition assay. Growth inhibition assays were carried out with exponentially growing cells. The cells were seeded into 24-well plates (20000/2 ml per well) about $24 \mathrm{~h}$ before drug treatment and exposed to drugs for $6 \mathrm{~h}$ followed by $72 \mathrm{~h}$ postincubation in drug-free medium or for $72 \mathrm{~h}$ of continuous incubation. Cytotoxic activity was determined by cell counting (Bhuyan et al., 1992) (cell number was determined with ZBI Coulter Counter) or by sulforhodamine assay (Skehan et al., 1990).

DNA thermal denaturation studies. Stabilization of secondary structure of DNA by TA was studied by determining melting temperatures of calf thy- 
mus DNA in the presence of $10 \mu \mathrm{M}$ triazoloacridinones in phosphate buffer $\left(7.5 \mathrm{mM} \mathrm{NaH} \mathrm{PO}_{4}, 1 \mathrm{mM}\right.$ EDTA, pH 7.0). Compounds tested were mixed with DNA at a $1: 4 \mathrm{drug} / \mathrm{bp}$ (base pair) molar ratio. Samples were heated over the range $45-95^{\circ} \mathrm{C}$ (using a heating rate of $1^{\circ} \mathrm{C} / \mathrm{min}$ ) and absorbance at $260 \mathrm{~nm}$ was monitored in a Varian Cary 300 Bio UV-Vis spectrophotometer equipped with a programmable heating unit. The 'melting' temperature $\left(t_{\mathrm{m}}\right)$ was read from the plot of relative hyperchromicity versus the temperature as the midpoint of the hyperchromic transition (Pawlak et al., 1983).

DNA viscometry studies. Viscometric measurements were performed as described previously (Reinert, 1991; Suh \& Chaires, 1995) in a Micro-Ubbelohde microviscometer with a $0.53 \mathrm{~mm}$ capillary (Schott) at $25^{\circ} \mathrm{C}$. Titration of ligands was performed by the addition of small volumes $(20 \mu \mathrm{l})$ of concentrated stock solution $(2 \mathrm{mM})$ in TE buffer $(10 \mathrm{mM}$ Tris/HCl, $1 \mathrm{mM}$ EDTA, $\mathrm{pH}$ 7.4) to the viscometer chamber containing calf thymus DNA ( $2 \mathrm{mM}$ in bp) sonicated to approx. $200 \mathrm{bp}$ fragments in TE buffer (Chaires et al., 1982). Relative viscosity of DNA in either the presence or absence of a ligand was calculated from the equation:

$\eta=\left(t-t_{0}\right) / t_{0}$

where $t$ is the observed flow time of the buffer containing DNA, and $t_{0}$ is the flow time of buffer alone. Intercalation of an aromatic chromophore between DNA base pairs induces lengthening and stiffening of DNA which is related to $r$, the ratio of the molar concentration of bound compound to the molar concentration of DNA base pairs. Viscosity data were plotted as $\log \left(\eta / \eta_{0}\right)$ versus $\log (1+2 r)$, where $\eta$ and $\eta_{0}$ are the intrinsic viscosities of sonicated DNA in the presence and in the absence of bound compound, respectively, and the slope value $\mathrm{m}$, was estimated. The slope value $m$ is between 2 and 3 for a monointercalating agent (Chaires et al., 1982).

Determination of interstrand DNA crosslinks. The fractions of renatured DNA were determined using nuclease $S_{1}$ assay as described previously by Konopa (1983) and the percentage of DNA with induced interstrand crosslinks was determined using nuclease $\mathrm{S}_{1}$ assay as described previously by Składanowski and Konopa (1994a). DNA in exponentially growing cells $\left(2 \times 10^{6}\right)$ was labeled by overnight incubation of cells in medium containing $\left[{ }^{3} \mathrm{H}\right]$ thymidine $(0.02 \mu \mathrm{Ci} / \mathrm{ml})$. Then, the cells were treated with different concentrations of the drugs studied for times indicated. In some experiments, cells were preincubated with $25 \mu \mathrm{M}$ aurintricarboxylic acid (ATA) for one cell doubling time depending on cell line (Benchokroun et al., 1995). For the experiments with confluent $\mathrm{NIH} 3 \mathrm{~T} 3$ cells, to reach contact inhibition, exponentially growing cells $\left(0.5 \times 10^{6}\right)$ were seeded $48 \mathrm{~h}$ prior to treatment and concomitantly during this time DNA was radiolabeled. After changing the medium, the cells were treated with TA for indicated times. In all cases, after treatment with the compounds the cells were transferred to test tubes and washed with PBS twice. After washing the cells were mixed with $0.2 \mathrm{ml}$ of lysing solution $(10 \mathrm{mM}$ Tris/ $\mathrm{HCl}, 10 \mathrm{mM}$ EDTA, $10 \mathrm{mM} \mathrm{NaCl}$, $0.5 \%$ SDS, $\mathrm{pH}$ 8.0) supplemented with proteinase $\mathrm{K}$ $(1 \mathrm{mg} / \mathrm{ml})$. After $1 \mathrm{~h}$ at $37^{\circ} \mathrm{C}, 1.8 \mathrm{ml}$ of denaturating solution (5.25 M sodium perchlorate, $1 \mathrm{mM}$ EDTA, $0.2 \%$ N-lauryl sarcosine, $20 \%$ methanol, $\mathrm{pH} 7.0$ ) was added and incubation was continued for additional $1 \mathrm{~h}$. DNA was denatured by heating at $50^{\circ} \mathrm{C}$ for $30 \mathrm{~min}$, then renatured by rapid dilution with $10 \mathrm{ml}$ of ice-cold zinc buffer ( $1 \mathrm{mM}$ zinc acetate, $5 \mathrm{mM}$ sodium acetate, $10 \mathrm{mM} \mathrm{NaCl}, \mathrm{pH} 4.4)$ and cooling at $-18^{\circ} \mathrm{C}$. The fraction of crosslinked DNA (FCR) was calculated according to the formula:

$F C R[\%]=\frac{F D S_{\text {treat }}-F D S_{\text {contr }}}{1-F D S_{\text {contr }}}$

where FDS is the ratio of radioactivity (dpm) measured in treated vs. non-treated with nuclease $S_{1}$ samples and defines the amount of dsDNA from cells treated with a drug $\left(F D S_{\text {treat }}\right)$ and non-treated cells $\left(F D S_{\text {contr }}\right)$. The relationship between drug concentration and fraction of crosslinked DNA was fitted to a linear equation and a $\mathrm{C}_{0}$ value - the concentration of triazoloacridinone at which the formation of the first DNA crosslink could be observed - was estimated by extrapolation.

For DNA crosslink evaluation in a cell-free system, radiolabeled and non-treated cells were lysed in lysis solution as described above. C-1305 was added to cell lysates to a final concentration of $75 \mu \mathrm{M}$. Following incubation of cell lysates in the dark at $37^{\circ} \mathrm{C}$, the fraction of crosslinked DNA was determined as described above.

Thermal and alkaline stability of interstrand DNA crosslinks. Cell lysates from control or C-1305 treated cells $(75 \mu \mathrm{M})$ were heated at $95^{\circ} \mathrm{C}$ for 15 min and then cooled in a methanol-dry ice bath for 2 min or alkalized ( $\mathrm{pH}$ 12.5) by the addition of 0.1 $\mathrm{M} \mathrm{NaOH}$ to $30 \mathrm{mM}$ for $30 \mathrm{~min}$ at room temperature followed by neutralization with $\mathrm{HCl}$. Samples were then processed for DNA crosslinking determination as described above.

\section{RESULTS}

The triazoloacridinone derivatives examined in this study have been selected to include analogs with divergent structures, covering a range of cytotoxic and anticancer activities (Table 1). All these 
compounds share the same core structure of TA with two varying elements: (1) ring substitutions in the position 5 or 8 , and (2) diaminoalkyl side chain.

\section{Stabilization of secondary structure of DNA}

Physicochemical drug-DNA interactions expressed as thermodynamic stabilization of DNA duplexes are of potential biological significance. All the triazoloacridinones studied shifted the DNA melting profiles upward when analyzed at $10 \mu \mathrm{M}$ drug concentration (1:4 drug/DNA base pair molar ratio). The resulting melting curves were monophasic (not shown), and the increases in DNA melting point $\left(\Delta t_{\mathrm{m}}\right.$ values) varied from 6.8 to $15.1^{\circ} \mathrm{C}$ depending on the chemical structure of TA (Table 2). Derivatives with a hydroxy group in position 8, such as C-1303 and C-1305, stabilized the double-stranded DNA structures most significantly. Compound C-1567, bearing a $t$-butyl group in position 8 , caused lower increase in DNA $t_{\mathrm{m}}$ than other triazoloacridinones. In a buffer with a higher concentration of $\mathrm{NaCl}(100$ $\mathrm{mM})$, corresponding to the physiological concentration, practically no increases in $\Delta t_{\mathrm{m}}$ were observed in the case of all TA (Table 2).

\section{Intercalation to DNA}

In DNA viscometric studies the slope values $\mathrm{m}$ derived from the equation described in Materials

Table 2. Parameters describing physicochemical interaction of triazoloacridinones with DNA.

Values are means \pm S.D. from at least three independent experiments.

\begin{tabular}{lrrc}
\hline \multirow{2}{*}{ Compound } & \multicolumn{2}{c}{ DNA duplex stabilization } & $\begin{array}{c}\text { Viscometric } \\
\text { measurement }\end{array}$ \\
\cline { 2 - 4 } & \multicolumn{2}{c}{${ }^{\mathrm{a} \Delta t_{\mathrm{m}}}{ }^{\mathrm{b}} \Delta t_{\mathrm{m} 1}$} & ${ }^{\mathrm{c}} \mathrm{m}$ slope \\
\cline { 2 - 4 } & \multicolumn{2}{c}{$\left[{ }^{\circ} \mathrm{C}\right]$} & - \\
\hline $\mathrm{C}-1233$ & $9.1 \pm 0.09$ & $-0.31 \pm 0.93$ & 2.74 \\
$\mathrm{C}-1296$ & $11.5 \pm 0.61$ & $1.20 \pm 0.24$ & 2.18 \\
$\mathrm{C}-1303$ & $13.1 \pm 1.50$ & $1.70 \pm 0.49$ & 3.36 \\
$\mathrm{C}-1305$ & $15.1 \pm 0.13$ & $2.00 \pm 0.03$ & 3.10 \\
$\mathrm{C}-1533$ & $8.1 \pm 0.21$ & $-0.93 \pm 0.23$ & 2.93 \\
$\mathrm{C}-1567$ & $6.8 \pm 2.20$ & $0.11 \pm 0.09$ & 1.24 \\
\hline
\end{tabular}

${ }^{\mathrm{a}} \Delta t_{\mathrm{m}^{\prime}}$ the increase in DNA melting temperature at drug to DNA base pairs 1:4 molar ratio for calf thymus DNA in phosphate buffer (7.5 mM NaH${ }_{2} \mathrm{PO}_{4}, 1 \mathrm{mM}$ EDTA, pH 7.0); ${ }^{\mathrm{b}} \Delta t_{\mathrm{m} 1}$, the increase in DNA melting temperature at drug to DNA base pairs 1:4 molar ratio for calf thymus DNA in phosphate buffer supplemented with $100 \mathrm{mM} \mathrm{NaCl}$; $\mathrm{m}$, slope of the function $\log \left(\eta / \eta_{0}\right)$ vs. $\log (1+2 \mathrm{r})$ is calculated from the intrinsic viscosities of sonicated calf thymus DNA, where $\eta$ and $\eta_{0}$ are respectively the intrinsic viscosity in the presence and in the absence of a compound, and $r$ is the ratio of the molar concentration of bound compound to the molar concentration of DNA base pairs. and Methods provided evidence for monointercalation for all triazoloacridinones studied except for the biologically inactive compound C-1567, bearing a $t$-butyl group in position 8 , for which the $\mathrm{m}$ slope value was 1.24. Moreover, for the derivatives with a hydroxyl group in position 8 (C-1303 and C-1305), the $\mathrm{m}$ slope value was higher than between 2 and 3 that is expected for monointercalating agents. Results are shown in Table 2.

\section{Induction of DNA interstrand crosslinks in tumor cells}

The ability to induce interstrand DNA crosslinks was determined using a procedure based on DNA denaturation-renaturation as described in Materials and Methods. DNA from drug-treated cells after induction of interstrand crosslinking and strand separation during denaturation renaturates more easily due to the zipper effect and this is the basis of many DNA crosslinking assays. Although the DNA denaturation-renaturation method is very sensitive for detection of DNA interstrand crosslinks, it is extremely susceptible to errors caused by damage to DNA, because the rate of renaturation is related to DNA length. Unfortunately, triazoloacridinones inhibit topoisomerases II (topo II), which results in the induction of topo II-associated double strand breaks (Skladanowski et al., 1999; Lemke et al., 2004). The induction of strand breaks was most probably the cause of unsuccessful initial experiments conducted to detect interstrand DNA crosslinks in HeLa $S_{3}$ and HL60 cells treated with C-1305, the most active compound from the triazoloacridinone group (Fig. 1A-B, open symbols). We were able to overcome this problem by pretreating cells with aurintricarboxylic acid (ATA), a compound known to inhibit the formation of topo II-DNA complexes and drug-induced DNA strand scission (Benchokroun et al., 1995). In all experiments, cells were incubated with $25 \mu \mathrm{M}$ of ATA for one cell doubling time. Under these conditions ATA had no effect on C-1305 cytotoxicity (not shown). Using a mild denaturation method it was found that C-1305 increased the fraction of crosslinked DNA in cells of two different tumor cell lines (HeLa $\mathrm{S}_{3}$ and HL60) as compared to control cells non-treated with ATA (Fig. 1A-B, closed symbols). The crosslinks induced in the presence of ATA were dependent on C-1305 concentration. The DNA interstrand crosslink formation was strictly dependent on active intracellular enzymes. C-1305 incubated with cell lysates, in which cellular enzymes were deactivated during lysis by detergent, did not cause any significant increase in the fraction of crosslinked DNA (Fig. 2). It should be stressed that the drug: DNA ratio in cell lysates was comparable to or even higher than those in whole cells. 
In other experiments, we abolished topo II activity in fibroblastic cells by growing them to confluency. It is known that contact growth inhibition of normal mouse fibroblasts NIH $3 \mathrm{~T} 3$ results in a decreased level of topoisomerase II $\alpha$ (down to negligible, around $0 \%$ of the normal level); the level of topoisomerase II $\beta$, normally constituting less than $20 \%$ of the total topoisomerase activity observed

A

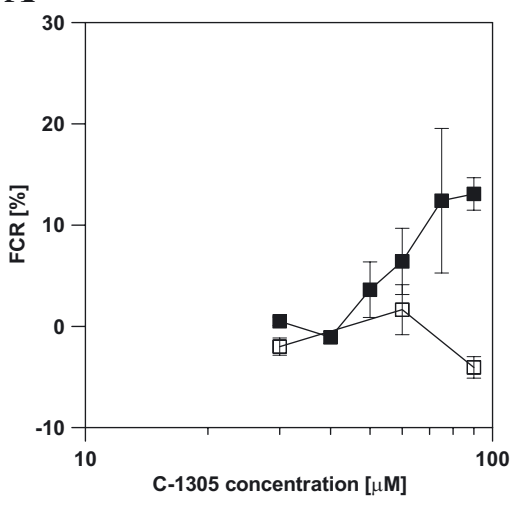

B

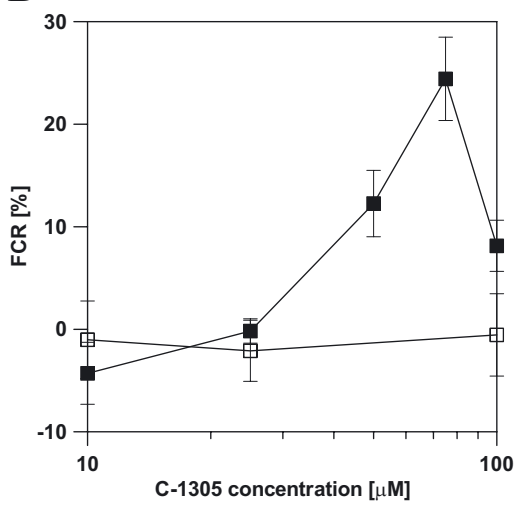

C

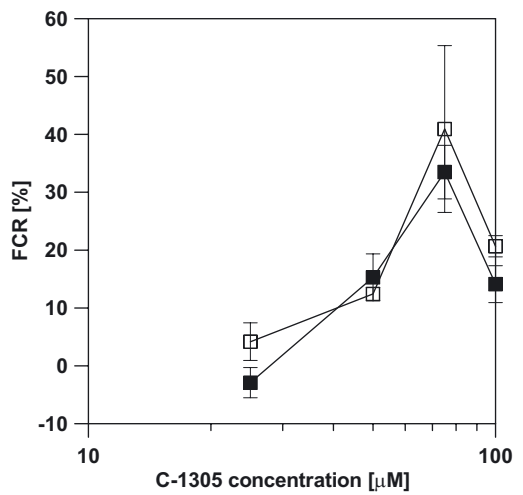

Figure 1. C-1305-induced interstrand crosslinking of genomic DNA.

HeLa $\mathrm{S}_{3}$ (A) and HL60 (B) cell lines at exponential or NIH 3T3 (C) cells at confluent phase of growth were pretreated with $25 \mu \mathrm{M}$ ATA before drug treatment $(\boldsymbol{\square})$, or grown in ATA-free medium ( $\square$ ), and treated with the drug for $3 \mathrm{~h}$ and then the fraction of crosslinked DNA (FCR) was measured using mild denaturation method as described in Materials and Methods. Values are means $( \pm$ S.D.) of three experiments.

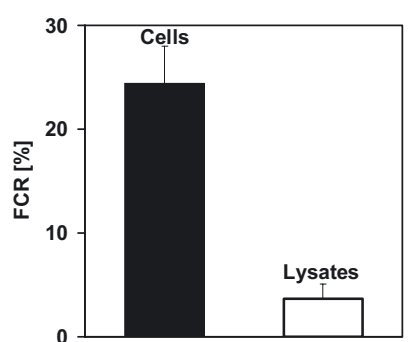

Figure 2. Characterization of C-1305-induced DNA interstrand crosslinks in HL60 cells pretreated with $25 \mu \mathrm{M}$ ATA and treated with $75 \mu \mathrm{M} \mathrm{C}-1305$ for $3 \mathrm{~h}$.

Whole cells $(\square)$ or cell lysates $(\square)$ were treated with the drug and the level of DNA crosslinks was evaluated using denaturation method described in Materials and Methods. Values are means $( \pm$ S.D.) of three experiments.

in dividing cells, remains unchanged (Isaacs et al., 1996; and citated publications). In all experiments, to reach contact inhibition (confluency), exponentially growing cells were seeded $48 \mathrm{~h}$ prior to C-1305 treatment. In confluent NIH 3T3 cells it was found that C-1305 induced a similar increase in the fraction of crosslinked DNA as that obtained in tumor cells pretreated with ATA (Fig. 1C, open symbols). It was also found that pretreatment of contact inhibited cells with ATA did not affect the DNA crosslinking induced by C-1305 (Fig. 1C, closed symbols). We observed no or only a minor increase in the fraction of crosslinked DNA when DNA from C-1305 treated cells was denaturated at $\mathrm{pH} 12.5,30 \mathrm{~min}$ or at $95^{\circ} \mathrm{C}$, 15 min (Fig. 3).

The ability of other TA to induce interstrand DNA crosslinks was determined for confluent NIH 3T3 cells which seemed to be a more proper model for studying DNA crosslinking than tumor cells artificially modified by pretreatment with ATA. For better comparison, all TA were studied at the same range of concentrations (10 to $100 \mu \mathrm{M})$. Five out of six selected TA induced a concentration-dependent

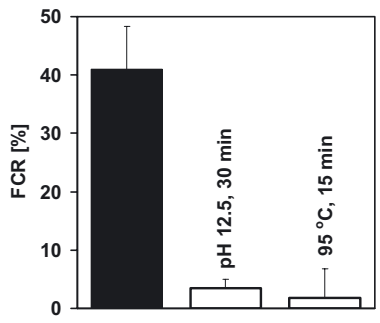

Figure 3. Thermal and alkali stability of DNA interstrand crosslinks induced by C-1305 in NIH 3T3 cells at confluent phase of growth.

Cells were treated with $75 \mu \mathrm{M}$ C-1305 for $6 \mathrm{~h}$ and the level of DNA crosslinking was evaluated after (ם) mild denaturation $\left(50^{\circ} \mathrm{C}, 30 \mathrm{~min}\right)$; alkali denaturation: $\mathrm{pH} 12.5,30$ $\mathrm{min}$; high temperature denaturation: $95^{\circ} \mathrm{C}, 15 \mathrm{~min}$. Values are means $( \pm$ S.D.) of three experiments. 
increase in the fraction of crosslinked DNA. Depending on the chemical structures of the TA studied, the maximum level of the fraction of crosslinked DNA varied from about 20 to $40 \%$ for the compound concentration amounting to 50 or $75 \mu \mathrm{M}$ for triazoloacridinones C-1233, C-1296, C-1303 and C-1305 (Fig. 4A-C). Moreover, it was found that compound C-1533 was the most effective DNA crosslinking agent among the TA studied, with about $80 \%$ level of the fraction of crosslinked DNA at $50 \mu \mathrm{M}$ com-

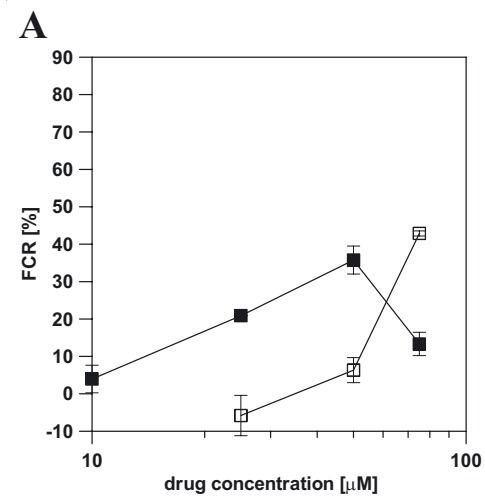

B

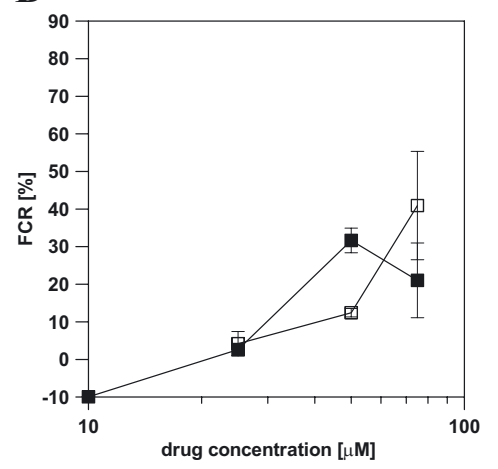

C

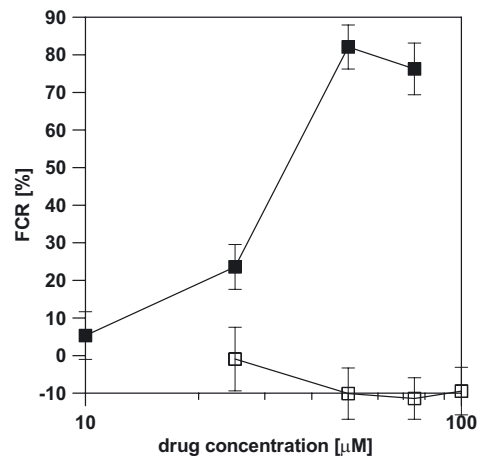

Figure 4. Interstrand crosslinking of genomic DNA induced by triazoloacridinones in NIH 3T3 cells at confluent phase of growth treated with the drugs for $6 \mathrm{~h}$.

Fraction of crosslinked DNA (FCR) was measured using denaturation method described in Materials and Methods. Panel A: C-1233 (匹), C-1296 (ㅁ); Panel B: C-1303 (ם),

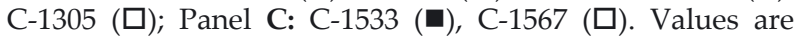
means $( \pm$ S.D.) of three experiments. pound concentration (Fig. 4C, closed symbols). For compound C-1567, bearing t-butyl group in position 8, no increase in the fraction of crosslinked DNA was observed (Fig. 4C, open symbols). Using a cross-validation method we also estimated the $\mathrm{C}_{0}$ value, which corresponds to a concentration of TA at which the first DNA crosslink could be detected by our method. Results are shown in Table 3 .

\section{Correlation between biological (cytotoxic) activity and drug-DNA binding parameters}

After demonstration of the capability of TA of noncovalent or covalent binding to DNA by intercalation or formation of interstrand DNA crosslinks in cells, respectively, an important question arose regarding the relevance of such abilities to the biological properties of these compounds. Answering this question was possible only indirectly by studying the correlation between the biological (cytotoxic) activity and the drug-DNA binding parameters. The biological activity data (Table 1 and 3) used for the correlation analysis were transformed to negative logarithms. The noncovalent drug-DNA binding parameters, $\Delta t_{\mathrm{m}}$ and $\mathrm{m}$ slope values (Table 3), were used directly. For the correlation analysis, the covalent binding parameter, $\mathrm{C}_{0}$ values, corresponding to the concentration at which the first crosslink could be detected, were transformed to negative logarithms. The correlations between the biological (cytotoxic) activity and the drug-DNA binding parameters were performed by regression analysis and expressed as correlation coefficients and the results are shown in Table 4.

There are two groups of correlation coefficients (in bold) higher than 0.8. The first group relates to cytotoxic activities ( $\mathrm{pEC}$ ) and indicates a positive correlation between the TA cytotoxic activi-

Table 3. Comparison between cytotoxic activity and the ability to induce interstrand crosslinks in DNA of NIH 3T3 cells for studied triazoloacridinones

\begin{tabular}{lrr}
\hline \multirow{2}{*}{ Compound } & \multicolumn{2}{c}{ NIH 3T3 cells } \\
\cline { 2 - 3 } & ${ }^{\mathrm{a} \mathrm{EC}_{90}[\mu \mathrm{M}]}$ & \multicolumn{1}{c}{$\mathrm{C}_{0}[\mu \mathrm{M}]$} \\
\hline $\mathrm{C}-1233$ & $64.3 \pm 1.30$ & $4.6 \pm 2.20$ \\
$\mathrm{C}-1296$ & $4.3 \pm 0.37$ & $37.2 \pm 7.60$ \\
$\mathrm{C}-1303$ & $7.1 \pm 1.20$ & $21.9 \pm 0.91$ \\
$\mathrm{C}-1305$ & $5.6 \pm 0.42$ & $23.7 \pm 9.90$ \\
$\mathrm{C}-1533$ & $71.3 \pm 1.70$ & $3.5 \pm 1.40$ \\
$\mathrm{C}-1567$ & $266.3 \pm 3.00$ & \multicolumn{1}{c}{${ }^{\mathrm{N}}$} \\
\hline
\end{tabular}

${ }^{\mathrm{a}} \mathrm{EC}_{90}$, the concentration of the compound inhibiting growth of cells by $90 \%$ after exposition to drugs for $6 \mathrm{~h}$ and $72 \mathrm{~h}$ postincubation in drug-free medium; ${ }^{b} \mathrm{C}_{0}$, the drug concentration at which the first DNA crosslink could be determined in confluent NIH 3T3 cells treated with the drug for $6 \mathrm{~h}$; ${ }^{\mathrm{c}} \mathrm{N}$, means that DNA crosslinks were not observed. 
Table 4. Correlation coefficients (R) between biological (cytotoxic) activity and drug-DNA binding parameters for studied triazoloacridinones ${ }^{\mathrm{a}}$

\begin{tabular}{|c|c|c|c|c|c|}
\hline \multicolumn{6}{|c|}{ Correlation coefficient $R$ values } \\
\hline & ${ }^{\mathrm{b}} \mathrm{pEC}{ }_{50 \text { HeLa }} 3$ & ${ }^{\mathrm{b}} \mathrm{pEC} \mathrm{C}_{90 \mathrm{NIH}}$ зТ3 & $\Delta t_{\mathrm{m}}$ & m slope & ${ }^{\mathrm{b}} \mathrm{pC}_{0}$ \\
\hline $\mathrm{pEC}_{50 \text { HeLa S3 }}$ & 1.000 & & & & \\
\hline $\mathrm{pEC}_{90 \mathrm{NIH} 3 \mathrm{T3}}$ & 0.818 & 1.000 & & & \\
\hline$\Delta t_{\mathrm{m}}$ & 0.801 & 0.907 & 1.000 & & \\
\hline m slope & 0.405 & 0.564 & 0.646 & 1.000 & \\
\hline $\mathrm{pC}_{0}$ & -0.862 & -0.995 & -0.814 & 0.146 & 1.000 \\
\hline
\end{tabular}

${ }^{a}$ Explanation of all abbreviations and symbols is given in Table 1,2 and $3 ;{ }^{b} \mathrm{pEC}_{50 \mathrm{HeLa} \mathrm{S3}}, \mathrm{pEC}_{90 \mathrm{NIH} 3 \mathrm{T3}}$ and $\mathrm{pC}_{0}$ are expressed as negative logarithms.

ties in two different cell lines. The second shows a positive correlation between the stabilization of DNA duplexes by triazoloacridinones $\left(\Delta t_{\mathrm{m}}\right)$ in low concentration phosphate buffer and the cytotoxic activity. However, no significant correlations were identified between the intercalation to DNA (m slope) and the cytotoxic activity, or between DNA duplex stabilization and intercalation to DNA. Negative correlations were found between DNA crosslink formation $\left(\mathrm{pC}_{0}\right)$ and the cytotoxic activity and other parameters. Compound C-1567 was excluded from the correlation calculations as it had no crosslinking ability.

\section{DISCUSSION}

The aim of our study was to investigate the ability of a series of six triazoloacridinones differing in chemical structure and the cytotoxic and antitumor activities (Table 1) to form noncovalent complexes with DNA as well as covalent interstrand DNA crosslinks. We also assessed the significance of these interactions for biological activity of TA.

The ability of TA to interact with DNA was examined using thermal denaturation or viscometric titration methods. All TA compounds examined were able to stabilize DNA duplexes with the increases in the 'melting' temperature of ctDNA, $\Delta t_{\mathrm{m}^{\prime}}$, ranging from 6.8 to $15.1^{\circ} \mathrm{C}$ for a drug/DNA molar ratio 1:4 (Table 2). These results confirm the ability of TA to interact noncovalently with DNA. The higher affinity for DNA in low salt buffer and a significant almost complete loss of a stabilization effect on the secondary structure of DNA in a buffer with a high concentration of $\mathrm{NaCl}(100 \mathrm{mM})$ point to a role of electrostatic interactions, probably between the positively charged side chain of TA and the polyanionic DNA phosphate backbone (Chaires et al., 1996). Modeling studies have suggested that the charged diaminoalkyl side chain of imidazoacridinone compounds can interact with DNA in the minor groove (Mazerski \& Muchniewicz, 2000), in addition to intercalation. Such interaction is likely for TA-DNA complexes. Those data indicated also that intercalation is not involved in the stabilization of secondary structure of DNA. The lack of stabilization of the secondary structure of DNA in a buffer with $100 \mathrm{mM} \mathrm{NaCl}$, corresponding to the salt concentration in the cell, indicates that this stabilizing effect could not appear in cells and influence the biological activity of TA. In view of the above observation, the positive correlation found between stabilization of secondary structure of DNA in low salt buffer and cytotoxic activity has no implication for the biological activity of TA. Viscometric titration data, the $\mathrm{m}$ slope values, provide evidence for TA monointercalation to DNA (Table 2). It is important to note that viscometric studies on binding to DNA are regarded as the most reliable assay for intercalation to DNA (Suh \& Chaires, 1995). Moreover, the presence of a hydroxyl group in position 8 of acridinone ring slightly increases the affinity for DNA compared to unsubstituted or alkyl- substituted derivatives, possibly due to additional hydrogen bonds with the DNA phosphate backbone. Triazoloacridinones with 8-OH group (C-1303, C1305), as noted (Cholody et al., 1990; Kusnierczyk et al., 1994), were considerably more potent antitumor agents than other derivatives. However, for the biologically non-active and non-crosslinking DNA compound C-1567, bearing a $t$-butyl group in position 8 , the $\Delta t_{\mathrm{m}}$ and $\mathrm{m}$ slope values were $6.8^{\circ} \mathrm{C}$ and 1.24, respectively, indicating that stabilization of the DNA duplex by this compound probably derived from electrostatic interactions of the side chain with DNA and not from its intercalation to DNA. This means that intercalation to DNA is necessary for the biological activity of TA. 
Among the TA derivatives tested there is no significant correlation between DNA duplex stabilization $\left(\Delta t_{\mathrm{m}}\right)$ and intercalation to DNA (m slope) (Table 4). This points to an additional manner of interactions of TA with DNA, in addition to intercalation. The weak correlation between intercalation to DNA (m slope) and the cytotoxic activity (pEC) suggests that intercalation to DNA does not play a major role in the mechanism of TA action important for their biological (cytotoxic) activity. Studies with related classes of intercalating drugs, such as imidazoacridinones (Dziegielewski et al., 2002), anthracenediones (Johnson et al., 1979), azaanthracenediones (Hazlehurst et al., 1995), 1-nitroacridine derivatives (Pawlak et al., 1983) or anthracyclines (Capranico et al., 1990) also repeatedly showed a poor correlation between the drug cytotoxic potency and physicochemical DNA binding affinity.

In several cases, for a number of classes of intercalating drugs, further studies revealed drug metabolic activation in cellular systems, leading to the formation of covalent DNA adducts (Pawlak et al., 1984; Skladanowski \& Konopa, 1994b). Therefore, the aim of our further studies was to investigate the ability of triazoloacridinones to form covalent interstrand DNA crosslinks and to assess the significance of this mode of binding to DNA for the biological activity of TA. Triazoloacridinones are topo II inhibitors since they are capable of blocking cleavable topo II-DNA complexes (Skladanowski et al., 1999; Lemke et al., 2004). This leads to DNA fragmentation during DNA denaturation step of DNA crosslinking determination, and thereby decreases the ability of DNA to renature. In consequence, the detection of DNA crosslinks declines or becomes impossible altogether. For instance, in DNA of HeLa $\mathrm{S}_{3}$ and HL60 cells treated with C-1305, it was not possible to detect interstrand crosslinks. However, we found that this triazoloacridinone induced interstrand DNA crosslinks in cells in which topo II activity was lowered or "switched off". Aurintricarboxylic acid inhibits the formation of topo II-DNA complexes (Benchokroun et al., 1995). Therefore, when HeLa $\mathrm{S}_{3}$ or HL60 cells were pretreated with ATA and then treated with C-1305, an increase in interstrand DNA crosslinks in a dose-dependent manner was observed. In other experiments, we significantly lowered topo II activity in fibroblast NIH $3 \mathrm{~T} 3$ cells by growing them to confluency. In confluent (contact-inhibited) cells, the level of topoisomerase II $\alpha$ decreases almost to $0 \%$, while the level of topoisomerase II $\beta$ remains unchanged (Isaacs et al., 1996). Triazoloacridinone C-1305 induced interstrand crosslinks in a dose-dependent manner also in DNA of confluent NIH 3T3. A similar level of crosslinked DNA was observed in confluent NIH 3T3 cells pretreated with ATA and then treated with C-1305. This result additionally, but indirectly, confirms the previous observations that $\mathrm{C}-1305$ is a specific poison of topoisomerase II $\alpha$.

Triazoloacridinone C-1305 did not produce any detectable DNA crosslinking when added directly to cell lysates, in which cellular enzymes were inactivated. Based on this observation two conclusions can be drawn. Firstly, the observed increase of the fraction of crosslinked DNA from cells treated with TA was not a result of their stabilization of the DNA structure by non-covalent interactions. Secondly, metabolic activation of TA was required for covalent crosslinking of DNA to occur. Pathways of metabolic activation of C-1305 are being currently under investigation. It seems probable that TA with the $8-\mathrm{OH}$ group in the acridinone ring, like imidazoacridinones (Mazerska et al., 1997), could be activated in cells by oxidation. Oxidation leads to the formation of reactive imino-quinone derivatives that could be able, similarly as reported for ellipticine (Meunier et al., 1988), to bind nucleophilic centers of cellular macromolecules, including DNA. The alkyldiamino residue might be also important for the DNA crosslinking ability of TA. It was shown for mitoxantrone and ametantrone that their alkyldiamino residues after enzymatic activation were involved in covalent binding and DNA crosslink formation (Dackiewicz et al., 1995; Skladanowski et al., 2000).

The DNA crosslinks produced by C-1305 were disrupted at alkaline $(\mathrm{pH} \mathrm{12.5,} 30 \mathrm{~min})$ or elevated temperature conditions $\left(95^{\circ} \mathrm{C}, 15 \mathrm{~min}\right)$, hence could neither be detected by alkaline elution procedures where DNA is exposed to alkali for a prolonged period of time nor methods based on thermal denaturation of DNA. It is not a unique property, since interstrand crosslinks in DNA formed by anthracyclines (Skladanowski \& Konopa, 1994a), anthracenediones (mitoxantrone) (Skladanowski et al., 2000) and bizelesine (Lee \& Gibson, 1993) are also alkali and thermally labile. Therefore, in this study we used a mild procedure developed in our laboratory which enables the detection of interstrand crosslinks in DNA at neutral $\mathrm{pH}$ and low temperature $\left(50^{\circ} \mathrm{C}\right)$.

We addressed the question of how relevant to the biological activities of TA is their ability to crosslink DNA by studying the correlation between these properties in a group of selected TA of divergent biological properties. Five from the six selected TA induced a concentration-dependent increase in the fraction of crosslinked DNA (FCR), reaching a maximum value of FCR equal to $20-40 \%$ mostly in cells treated with 50 or $75 \mu \mathrm{M}$ TA. In some cases, in cells treated with higher concentrations of TA, the fraction of crosslinked DNA decreased as a consequence of induction of apoptosis and the fragmentation of DNA (Augustin \& Konopa, 1999; Augustin et al., 2000; 2006). Moreover, for compound C-1533, 
the fraction of crosslinked DNA was about $80 \%$ at $50 \mu \mathrm{M}$ concentration of this compound. At the moment, it seems probable that the latter compound compared to the other TA studied is a less effective topo II inhibitor or is transported to cells and undergoes metabolic activation more efficiently. Further studies are required to clarify this notion. Compound C-1567, bearing a $t$-butyl group in position 8 , hence not intercalating to DNA, did not induce any increase in the fraction of crosslinked DNA. This observation suggests that probably intercalation of TA to DNA could be a necessary step for the formation of interstrand DNA crosslinks via positioning the drug molecules within DNA prior to the covalent reaction. However, it is also possible that position 8 in TA is important for their ability to crosslink DNA. It is interesting to note that all $\mathrm{TA}$ with a substituent in position 8 other than $\mathrm{OH}, \mathrm{NO}_{2} \mathrm{Cl}$ or $\mathrm{CH}_{3}$, do not exhibit antitumor activity (Cholody et al., 1990).

The negative correlations between the ability to form DNA crosslinks expressed as the $C_{0}$ value and their cytotoxic activities expressed as $\mathrm{EC}_{50}$ or $\mathrm{EC}_{90}$ values were rather surprising and unexpected. In previous similar studies, concerning 1-nitroacridines (Pawlak et al., 1984) and anthracyclines (Skladanowski \& Konopa, 1994b), on the relevance of the capability of DNA crosslinking to the biological activity of these compounds, a positive correlation between these two parameters was found, suggesting a crucial role of the ability to crosslink DNA for the biological activity. Correlations between the ability of the compounds studied to form DNA crosslinks and the cytotoxic properties were calculated for the five TA which induced DNA crosslinking. In the case of C-1567, which is biologically inactive and does not form DNA crosslinks, we observed a reverse situation - a positive relation between the mentioned properties. This discrepancy does not allow one to make conclusions concerning the relevance of the ability to crosslink DNA to the biological properties of TA. This discrepancy might stem from an unknown factor influencing the assay of DNA crosslinking. This influence is very likely to result from the topo II poison properties of TA which may interfere with the DNA crosslinking assay in a more complicated and unpredictable manner than was assumed and could be solved in further more datailed studies.

In conclusion, we have shown here that TA intercalate to DNA, but this ability is not crucial for the biological activity of these compounds. After previous metabolic activation, TA induce formation of covalent interstrand crosslinks in DNA of tumor cells. The DNA crosslinking ability is usually crucial for the biological activity of compounds exhibiting such property. However, in the case of the TA studied, it was impossible to validate the relevance of the ability to crosslink DNA to their biological activity. Moreover, the ability to induce interstrand crosslinking of DNA seems to be involved in the mechanism of action of TA, beside that of poisoning of topo II. Such a dual mechanism of action additionally supports the interest in TA, especially C-1305, as promising antitumor agents.

\section{Acknowledgements}

We are grateful to Dr. Jan Mazerski from our department for helpful discussions and methodological suggestions. This work was partially supported by the Committee for Scientific Research (KBN), grant no. 6 P05A 00220.

\section{REFERENCES}

Arjunan P, Arora SK, Cholody WM (1993) Structural studies on DNA binding drugs: crystal structure and molecular dynamics studies of triazoloacridinones. Acta Crystallogr B 46: 96-101.

Augustin E, Konopa J (1999) Cell cycle and apoptosis induced by antitumor triazoloacridinones in tumor cells. Folia Histochem Cytobiol 37 (Suppl 1): 41.

Augustin E, Plocka E, Konopa J (2000) Induction of cell death (apoptosis) by antitumor triazoloacridinones in tumor cells. Drugs Metab Rev 32 (Suppl 1): 33.

Augustin E, Mos-Rompa A, Skwarska A, Witkowski JM, Konopa J (2006) Induction of G2/M phase arrest and apoptosis of human leukemia cells by potent antitumor triazoloacridinone C-1305. Biochem Pharmacol 72: 1668-1679.

Benchokroun Y, Coupie J, Larsen AK (1995) Aurintricarboxylic acid, a putative inhibitor of apoptosis, is a potent inhibitor of DNA topoisomerase II in vitro and in Chinese hamster fibrosarcoma cells. Biochem Pharmacol 49: 305-313.

Bhuyan BK, Smith KS, Adams EG, Petzold GL, McGovren JP (1992) Lethality, DNA alkylation, and cell cycle effects of adozelesin (U-73975) on rodent and human cells. Cancer Res 52: 5687-5692.

Capranico G, Zunino F, Kohn KW, Pommier Y (1990) Sequence-selective topoisomerase II inhibition by anthracycline derivatives in SV40 DNA: relationship with DNA binding affinity and cytotoxicity. Biochemistry 29: 562-569.

Chaires JB, Dattagupta N, Crothers DM (1982) Studies on interaction of anthracycline antibiotics and deoxyribonucleic acid: equilibrium binding studies on interaction of daunomycin with deoxyribonucleic acid. Biochemistry 21: 3933-3940.

Chaires JB, Satyanarayana S, Suh D, Fokt I, Przewloka T, Priebe W (1996) Parsing the free energy of anthracycline antibiotic binding to DNA. Biochemistry 35: 20472053.

Cholody WM, Martelli S, Konopa J (1990) 8-Substituted 5-[(aminoalkyl)amino]-6H-v-triazolo[4,5,1-de]acridin-6ones as potential antineoplastic agents. J Med Chem 33: 2852-2856.

Cholody WM, Martelli S, Konopa J (1992) Chromophoremodified antineoplastic imidazoacridinones. Synthesis and activity against murine leukemias. J Med Chem 35: 378-382. 
Dackiewicz P, Skladanowski A, Konopa J (1995) ${ }^{32}$ P-postlabelling analysis of adducts formed by mitoxantrone and amentantrone with DNA and homopolydeoxyribonucleotides after enzymatic activation. Chem Biol Interact 98: 153-166.

Dziegielewski J, Slusarski B, Konitz A, Skladanowski A, Konopa J (2002) Interaction of imidazoacridinones to DNA and its relevance to cytotoxic and antitumor activity. Biochem Pharmacol 63: 1653-1666.

Hazlehurst LA, Krapcho AP, Hacker MP (1995) Correlation of DNA reactivity and cytotoxicity of a new class of anticancer agents: azaanthracenediones. Cancer Lett 91: 115-124.

Isaacs RJ, Harris AL, Hickson ID (1996) Regulation of human topoisomerase II $\alpha$ gene promoter in confluencearrested cells. J Biol Chem 271: 16741-16747.

Johnson RK, Zee-Cheng RK, Lee WW, Acton EM, Henry DW, Cheng CC (1979) Experimental antitumor activity of aminoanthraquinones. Cancer Treat Rep 63: 425-439.

Kapuscinski J, Darzynkiewicz Z (1985) Interactions of antitumor agents ametantrone and mitoxantrone (novatrone) with double-stranded DNA. Biochem Pharmacol 34: 4203-4213.

Konopa J (1983) Adriamycin and daunomycin induce interstrand DNA cross-links in HeLa S3 cells. Biochem Biophys Res Commun 110: 819-826.

Kusnierczyk H, Cholody WM, Paradziej-Lukowicz J, Radzikowski C, Konopa J (1994) Experimental antitumor activity and toxicity of the selected triazolo- and imidazoacridinones. Arch Immunol Ther Exp 42: 414423.

Lee CS, Gibson NW (1993) DNA interstrand cross-links induced by cyclopropylpyrroloindole antitumor agent Bizelesin are reversible upon exposure to alkali. Biochemistry 32: 9108-9114.

Lemke K, Poindessous V, Skladanowski A, Larsen AK (2004) The antitumor triazoloacridone C-1305 is a topoisomerase II poison with unusual properties. Mol Pharmacol 66: 1035-1042.

Lemke K, Wojciechowski M, Laine W, Bailly C, Colson P, Baginski M, Larsen AK, Skladanowski A (2005) Induction of unique structural changes in guanine-rich DNA regions by the triazoloacridinone C-1305, a topoisomerase II inhibitor with antitumor activity. Nucleic Acids Res 33: 6034-6047.

Mazerska Z, Augustin E, Dziegielewski J, Cholody WM, Konopa J (1996) QSAR of acridines. III. Structure-activity relationship for antitumor imidazoacridinones and intercorrelation between in vivo and in vitro tests. AntiCancer Drug Des 11: 73-88.
Mazerska Z, Zamponi S, Marassi R, Martelli S (1997) Electrochemical oxidation of antitumor imidazoacridinone derivatives and the reference 2-hydroxyacridinone. J Electroanal Chem 427: 71-78.

Mazerski J, Muchniewicz K (2000) The intercalation of imidazoacridinones into DNA induces conformational changes in their side chain. Acta Biochim Polon 47: 6578.

Meunier G, De Montauzon D, Bernadou J, Grassy G, Bonnafous M, Cros S, Meunier B (1988) The biooxidation of cytotoxic ellipticine derivatives: a key to structure-activity relationship studies? Mol Pharmacol 33: 93-102.

Pawlak K, Matuszkiewicz A, Pawlak JW, Konopa J (1983) The mode of action of cytotoxic and antitumor 1-nitroacridines. I. The 1-nitroacridines do not exert their cytotoxic effects by physicochemical binding with DNA. Chem Biol Interact 43: 131-149.

Pawlak K, Pawlak JW, Konopa J (1984) Cytotoxic and antitumor activity of 1-nitroacridines as an after effect of their interstrand DNA crosslinking. Cancer Res 44: 4289-4296.

Reinert KE (1991) DNA-helix bending, stiffening, and elongation on ligand binding; analysis for several DNAdrug systems, general viscometric DNA response and stereochemical implications. J Biomol Struc Dynam 9: 331-352.

Skehan P, Storeng R, Scudiero D, Monks A, McMahon J, Vistica D, Warren JT, Bokesch H, Kenney S, Boyd MR (1990) New colorimetric cytotoxicity assay for anticancer-drug screening. J Nat Cancer Inst 82: 1107-1112.

Skladanowski A, Konopa J (1994a) Interstrand DNA crosslinking induced by anthracyclines in tumour cells. Biochem Pharmacol 47: 2269-2278.

Skladanowski A, Konopa J (1994b) Relevance of interstrand DNA crosslinking induced by anthracyclines for their biological activity. Biochem Pharmacol 47: 2279-2287.

Skladanowski A, Larsen AK, Konopa J, Lemke K (1999) Inhibition of DNA topoisomerase II by antitumor triazoloacridinones in vitro and in tumor cells. Proc Am Assoc Cancer Res 40: 681.

Suh D, Chaires JB (1995) Criteria for the mode of binding of DNA binding agents. Bioorg Med Chem 3: 723-728.

Węsierska-Gądek J, Schloffer D, Gueorguieva M, Uhl M, Skladanowski A (2004) Increased susceptibility of poly(ADP-ribose) polymerase-1 knockout cells to antitumor triazoloacridone C-1305 is associated with permanent $G_{2}$ cell cycle arrest. Cancer Res 64: 4487-4497. 